\title{
卵巣成熟囊胞性奇形種再発症例についての検討
}

\author{
東京都済生会中央病院 \\ 大熊優子、西山紘子、塚田ひとみ、河西明代、 \\ 小野寺成実、弟子丸亮太、岸 郁子
}

\section{Recurrent Cases of Ovarian Mature Cystic Teratoma}

Yuko Okuma, Hiroko Nishiyama, Hitomi Tsukada, Akiyo Kawanishi,

Narumi Onodera, Ryota Deshimaru, Ikuko Kishi

Tokyo Saiseikai Central Hospital

\begin{abstract}
Objective: The objective of this study was to assess the risk of recurrence of ovarian mature cystic teratoma (OMCT) and to evaluate the feasibility of ovarian-conserving surgery.

Methods: This retrospective clinical study investigated patients with OMCT who underwent laparoscopic surgery between January 2014 and March 2017.

Results: Recurrence of OMCT was observed in 7 of 81 patients (8.6\%)-three patients (3.7\%) showed ipsilateral recurrence, and four patients (4.9\%) showed recurrence in the contralateral ovary. Patients with recurrence (mean age 22.5 years [range 15-30 years]) were younger than those without recurrence (mean age 33.5 years [range 16-63 years]). No significant intergroup differences were observed in gravidity, parity, cyst size, intraoperative cyst rupture (cysts that did or did not rupture), number of cysts, and laterality.

Conclusion: The recurrence tendency of OMCT in adolescents and in patients in their early 20s was higher than that in older patients. Cystectomy should be considered in children and patients of reproductive age for conservation of the affected ovary. An initial adnexectomy may not obviate the risk of multiple subsequent surgeries because OMCT may recur in the contralateral ovary.
\end{abstract}

Key words: ovarian mature cystic teratoma, recurrence, cystectomy

\section{【緒 言】}

卵巣成熟囊胞性奇形腫（以下奇形腫）は良性卵 巣腫瘍の約20～40\%を占め、10～30歳代で最も頻 度が高い ${ }^{1)}$ 。治療法としては卵巣機能温存のため に腫瘍核出術を選択することが多い。しかし、5 \%未満と頻度は少ないが温存後の卵巣に再発する ことが報告されており ${ }^{2-5)}$ 、再発による複数回手術 は避けたいところである。一方、卵巣腫瘍茎捻転 （以下茎捻転）症例や腫瘍径が大きく悪性を否定 できない症例等では片側付属器切除術を選択する ことがある。この場合、同側卵巣への再発を避け られるメリットはあるが、将来対側卵巣への何ら かの手術が必要となったときには、術後の卵巣機
能低下あるいは喪失が懸念される。従って、卵巣 に対する手術は、患側卵巣に対する疾患再発のデ メリットと卵巣機能温存のメリットを比較検討し たうえで術式選択を行う必要がある。

奇形腫再発に関する報告は少なく、再発症例の 臨床的特徵に関して一定の見解を得られていな い。そこで、奇形腫再発により当院で再手術を行 った症例について、初発時と再発時の患者背景や 術中所見を調查し、臨床的特徴を検討した。また、 初回手術時における術式選択の参考となりうる因 子の抽出を試みた。

\section{【対象と方法】}

2014年 1 月から2017年 3 月までに当院で卵巣腫 
瘍に対して腹腔鏡下手術を行った症例のうち、術 後病理診断で奇形腫と診断された症例を対象とし て後方視的に検討した。診療録から手術時の年齢、 妊娠出産歴、腫瘍最大径、術式、術中腫瘍破綻の 有無、腫瘍の単房性・多房性、腫瘍の片側性・両 側性、過去の手術歴を抽出した。既往手術の術式 は、初回手術施行施設からの紹介患者と当院で手 術歴のある患者以外では、問診のみで確認した。 初発群は、奇形腫に対して手術既往がなく初めて 手術する症例とした。再発群は、奇形腫に対して 手術既往があり、初回手術の同側卵巣に病変が認 められた症例と、対側卵巣に病変が認められた症 例とした。再発の診断は、全例経腟超音波検査と MRI検査で行った。初回手術での不完全切除の可 能性を除外するため、同側卵巣への再発は術後 24 カ月以降で新規に病変が認められたものと定義し た ${ }^{5)}$ 。再発までの期間は、他院手術例では問診の みで確認した。当院手術例では、術後のフォロー アップとして経胵超音波検査を術後 1 カ月以内と 術後 $3 \sim 6$ か月後に施行し、術後 $1 \sim 2$ 年以降は 検診で超音波検査を受けるように指導しているた め、診療録または問診で確認した。2 群間の統計 学的検討は、マン・ホイットニーのU検定、また はフィッシャーの正確確立検定で行った。

\section{【結果】}

2014年 1 月から2017年 3 月までに当院で卵巣腫 瘍に対して腹腔鏡下手術を行った症例のうち、術 後病理診断で奇形腫と診断された症例は 81 症例で
あった。初発群は74症例 (91.4\%)、再発群は 7 症 例 (8.6\%)であった(表 1 )。同側再発は3症例 (3.7\%) で認められ、うち 1 症例は片側付属器切除術後の 対側卵巣に 2 回発症し、計 3 回手術を受けていた。 付属器切除術または腫瘍核出術後の対側卵巣への 新規病変は 4 症例 ( $4.9 \%)$ で認められた。

初発群、再発群初発、再発群再発の手術時の年 齢の中央值は、33.5歳（16～63歳）、22.5歳（15～ 30歳)、30歳 (23 45歳) であり、再発群初発時 は初発群と比較して統計学的有意差をもって若い 傾向にあった $(\mathrm{p}<0.01)$ 。再発群再発時と初発群 では有意差を認めなかった。初発群、再発群初発、 再発群再発の手術時腫瘍最大径の中央值は $8 \mathrm{~cm}$ $(3 \sim 14 \mathrm{~cm}) 、 7.5 \mathrm{~cm}(5 \sim 10 \mathrm{~cm}$ 、不明 4 症例)、 $5.5 \mathrm{~cm}(3.5 \sim 8 \mathrm{~cm})$ で統計学的有意差を認めな かった。また、初発群、再発群初発時、再発群再 発時の経妊率 $(27.0 \% 、 0 \% 、 0 \%) 、$ 経産率 $(22.0 \%$ 、 $0 \% 、 0 \%)$ 、多房性の比率 $(23.0 \% 、 20.0 \% 、 37.5$ $\%)$ 、再側性の比率 $(17.6 \% 、 20.0 \% 、 12.5 \%)$ 、術 中破綻率 $(38.9 \% 、 75.0 \% 、 12.5 \%)$ には統計学的 有意差を認めなかった（表 2 )。再発群初発時に おいて、腫瘍の単房性・多房性と片側性・両側性 は3症例ずつ、術中破綻の有無は4症例で不明であ った。

術式について、初発群74症例では、腫瘍核出術 57 症例、片側付属器切除術 15 症例、両側付属器切 除術 1 症例、片側腫瘍核出・他側付属器切除術 1 症例であった。付属器切除を選択した理由は、閉 経後または周閉経期 $(n=10) 、$ 本人希望 $(n=3) 、$

表 1 当科における2014年1月～2017年3月の奇形腫再発症例

\begin{tabular}{|c|c|c|c|c|c|c|c|c|c|c|c|}
\hline 症例 & $\begin{array}{l}\text { 手術時の } \\
\text { 年齡 }\end{array}$ & 経好 & 経産 & 再発側 & $\begin{array}{l}\text { 再発時の年粿 } \\
\text { 再発までの年数 }\end{array}$ & $\begin{array}{l}\text { 再発時の } \\
\text { 骾無经 }\end{array}$ & 術式 & $\begin{array}{l}\text { 手術時の } \\
\text { 䯠重径 }\end{array}$ & 個数 & 術中破綻 & 捻転 \\
\hline \multirow[t]{3}{*}{1} & 22 & 0 & 0 & - & - & - & 開腹左SO & $10 \mathrm{~cm}$ & 左1個 & なし & なし \\
\hline & 28 & 0 & 0 & 対側 & 27 歲、5年9カ月 & $8 \mathrm{~cm}$ & 腹腔鏡下右核出術 & $8 \mathrm{~cm}$ & 右多房性 & なし & なし \\
\hline & 33 & 0 & 0 & 同側 & 30 歲、2年9力月 & $1.3 \mathrm{~cm}$ & 腹腔鏡下右核出術 & $4 \mathrm{~cm}, 1 \mathrm{~cm}$ & 右2個 & 不明 & なし \\
\hline \multirow[t]{2}{*}{2} & 16 & 0 & 0 & - & - & - & $\begin{array}{c}\text { 開腹右SO、 } \\
\text { 左核出術 }\end{array}$ & 不明 & $\begin{array}{l}\text { 右1個、 } \\
\text { 左1個 }\end{array}$ & なし & $\begin{array}{l}\text { あり、 } \\
\text { なし }\end{array}$ \\
\hline & 29 & 0 & 0 & 同側 & 20歲、4年 & $5 \mathrm{~cm}$ & 腹腔鏡下左核出術 & $\begin{array}{l}3 \mathrm{~cm} \times 5 \text { 個 } \\
(8 \mathrm{~cm})\end{array}$ & 右5個 & あり & なし \\
\hline \multirow[t]{2}{*}{3} & 23 & 不明 & 不明 & - & - & - & 開変右核出術 & 不明 & 不明 & 不明 & 不明 \\
\hline & 45 & 1 & 1 & $\begin{array}{l}\text { 同側、 } \\
\text { 対側 }\end{array}$ & 45歲、22年 & $\begin{array}{l}\text { 右 } 5.8 \mathrm{~cm} \text { 、 } \\
\text { 左 } 3.8 \mathrm{~cm}\end{array}$ & $\begin{array}{r}\text { 腹腔鏡下右SO、 } \\
\text { 左核出術 }\end{array}$ & $\begin{array}{l}5 \mathrm{~cm} \\
4 \mathrm{~cm}\end{array}$ & $\begin{array}{l}\text { 右1個、 } \\
\text { 左1個 }\end{array}$ & なし & $\begin{array}{l}\text { なし、 } \\
\text { なし }\end{array}$ \\
\hline \multirow[t]{2}{*}{4} & 15 & 0 & 0 & - & - & - & 開腹左SO & 不明 & 不明 & 不明 & あり \\
\hline & 31 & 0 & 0 & 対側 & 31歳、14年 & $3.6 \mathrm{~cm}$ & 腹腔鏡下右核出術 & $4 \mathrm{~cm}$ & 右1個 & なし & なし \\
\hline \multirow[t]{2}{*}{5} & 16 & 0 & 0 & - & - & - & 腹腔鏡下右核出術 & 不明 & 不明 & 不明 & 不明 \\
\hline & 23 & 0 & 0 & 対側 & 23歳、7年 & $5 \mathrm{~cm}$ & 腹腔鏡下左核出術 & $6 \mathrm{~cm}$ & 左1個 & なし & なし \\
\hline \multirow[t]{2}{*}{6} & 23 & 0 & 0 & - & - & - & 腹腔鏡下左核出術 & $7 \mathrm{~cm}$ & 左1個 & $\begin{array}{l}\text { 意図的な } \\
\text { 襄腫穿刺· } \\
\text { 内容吸引 }\end{array}$ & あり \\
\hline & 26 & 0 & 0 & 対側 & 26傶、3年 & 不明 & 腹腔鏡下右核出術 & $3.5 \mathrm{~cm}$ & 右1個 & なし & なし \\
\hline \multirow[t]{2}{*}{7} & 30 & 0 & 0 & - & - & - & 腹腔鏡下右核出術 & $5 \mathrm{~cm}$ & 右1個 & なし & なし \\
\hline & 44 & 4 & 3 & 対側 & 41㦱、11年 & 不明 & 腹腔鏡下左SO & $6 \mathrm{~cm}$ & 左1個 & なし & なし \\
\hline
\end{tabular}

SO : 付属器切除術 


\begin{tabular}{|c|c|c|c|c|c|c|c|}
\hline & $\begin{array}{l}\text { 初発年糩 } \\
\text { (中央値) }\end{array}$ & 経好率 & 経産率 & $\begin{array}{l}\text { 腫重最大径 } \\
\text { (中央値) }\end{array}$ & 多房性率 & 両側性事 & 術中破綻率 \\
\hline $\begin{array}{l}\text { 初発群 } \\
\text { (74症例) }\end{array}$ & 33.5 歳 & $27.0 \%$ & $22.0 \%$ & $8.0 \mathrm{~cm}$ & $23.0 \%(17 / 74)$ & $17.6 \%(13 / 74)$ & $\begin{array}{c}38.9 \%(28 / 72) \\
\text { 不明2症例 }\end{array}$ \\
\hline $\begin{array}{l}\text { 再発群 } \\
\text { (8庭例) }\end{array}$ & 22.5 歳 & $0.0 \%$ & $0.0 \%$ & $\begin{array}{l}7.5 \mathrm{~cm} \\
\text { 不明4症例 }\end{array}$ & $\begin{array}{c}20.0 \%(1 / 5) \\
\text { 不明3应例 }\end{array}$ & $\begin{array}{c}20.0 \%(1 / 5) \\
\text { 不明3症例 }\end{array}$ & $\begin{array}{c}75.0 \%(3 / 4) \\
\text { 不明4症例 }\end{array}$ \\
\hline
\end{tabular}

充実成分を認めるがMRIで造影剂使用できず $(n=2)$ 、荎捻転 $(n=2)$ であった。茎捻転に対し て腫瘍核出術を施行したものは 4 症例であった。 茎捻転 6 症例の組織所見は、付属器切除術 2 症例 のうち 1 症例で「大部分が出血性壊死」、腫瘍核 出術 4 症例のうち 1 症例で「虚血性変化にそしい」 との所見があったが、その他の 4 症例では不明で あった。再発群 8 症例の術式は、腫瘍核出術 5 症 例、片側付属器切除術 1 症例、片側腫瘍核出 - 他 側付属器切除 1 症例であった。

\section{【考察】}

今回の検討では初発群と比較して、再発群にお いて初回手術時の年齢が有意に低かったが、経妊 率、経産率、腫瘍最大径、単房性・多房性、片側 性・両側性、術中破綻率では有意差を認めなかっ た。10代～20代前半での初発症例は、それ以降の 年代での初発症例より再発しやすい可能性があ る。奇形腫の再発を検討した文献は少ないが、全 年齢層での再発率は $5 \%$ 未満であると報告されて いる ${ }^{2.5)}$ 。18〜 19歳以下の小児では再発率が5.3〜 $10.6 \%$ との報告があり ${ }^{6-8)}$ 、全年齢層と比較すると 若年での再発率が高いと考えられる。

腫瘍最大径、単房性・多房性、片側性・両側性、 術中破綻率、の 4 項目に拈いては、初発群と再発 群初発時で有意差を認めなかった。年齢以外の因 子として、Labergeらは開腹核出術後の同側再発 は $0 \%$ に対して腹腔鏡下核出術後の同側再発が $4.2 \%$ あり、術式が再発に影響していると報告し ている5)。一方、Rogersらは18歳以下の患者の検 討において術式は再発に影響しなかったと報告し ている ${ }^{6)}$ 。今回の検討では再発群が7症例と少数 であり、またその約半数の症例で初発時の情報を 得られなかったことが、検討結果に影響している 可能性がある。初発群と再発群再発時の比較では 全項目で有意差を認めなかった。

今回の検討は後方視的であり、当院での腹腔鏡 下手術症例のうち既往手術歴のある症例に関して 初発時の特徴を検討している。再発したが手術を 受けていない症例や再発時に開腹術を受けた症 例、再発していても当院を受診していない症例に
ついては検討できていない。また、再発群は 7 症 例と少数での検討となった。しかし、少数の検討 であっても初発群と比較して再発群の初回手術時 の年齢が有意に低い結果となり、奇形腫が再発し 手術が必要になる患者は初回手術時に若年であっ たという臨床的特徵があると考えられた。本検討 において、初発群が再発していないことを確認で きる期間は最長でも 3 年 2 か月だが、再発群では 初発から再発までの期間が 2 年 9 力月から 22 年で あり、観察期間に両群間で差がある。よって、初 発群の中には今後再発する症例が含まれているこ とが推測される。再発群のうち、 3 年 2 か月以内 に再発が確認されたのは 2 症例であった。初回手 術症例の長期的な術後観察研究では結果が異なる 可能性があるが、再発症例が少なく当院では対象 が限られるため、今回は後方視的な研究を行った。

術式に関して、生殖可能年齢患者の奇形腫に対 しては患側卵巣の温存を目的として腫瘍核出術を 行うことが望ましいが、付属器切除術を選択する 可能性がある症例として茎捻転症例や腫瘍径が大 きいため悪性が否定できない症例が挙げられる。 茎捻転により卵巣組織が壊死に陥っているか否か は、術前や術中所見での推測が困難であり、どの 所見が判別に有用であるかは明らかでない ${ }^{8-10)}$ 。 手術時の卵巣色調が不良であっても、付属器切除 標本でviableな卵巣組織が確認できる症例がある という報告もある ${ }^{8)}$ 。自験でも1症例は「虚血性 変化にそしい」との所見であった。従って、茥捻 転症例であっても、生殖可能年齢患者ではまず腫 瘍核出術が衔められる。

術前診断で境界悪性以上の症例は付属器切除を 含めた開腹卵巣癌基本術式が推奨される ${ }^{11)}$ 。しか し、良性卵巣腫瘍の診断のもとで腫瘍核出術を施 行し術後病理診断で境界覀性または悪性腫瘍と診 断される症例が諸家から報告されている。良性と の鑑別は超音波検查・MRI検査などの画像診断や 腫瘍マーカーで行うこととなるが、境界悪性腫瘍 に関しては特異的な所見にそしく鑑別が困難とさ れている ${ }^{12)}$ 。また、術前に奇形腫の悪性転化を診 断する方法は確立されていない。単独で悪性を示 唆できる因子はなく、年齢60歳以上、腫瘍径 
$100 \mathrm{~mm}$ 以上、血清 SCC 抗原 ・ 血清 CEA高值、 MRIで造影効果を有する充実成分を認める、など の因子で総合的に判断する必要がある ${ }^{13,14)}$ 。従っ て、妊孕性温存の必要があり腫瘍径が $100 \mathrm{~mm}$ 上ある症例では、その他に前述の因子が認められ なければ、術後病理診断の結果によっては追加手 術が必要になる可能性を十分に説明し、まず腫瘍 核出術を選択できると考えられた。

\section{【結語】}

今回の検討において、再発群では初回手術時の 年齢が低く、低年齢での手術は術後再発や、将来 的な卵巣機能低下の可能性があることを患者と家 族に説明する必要がある。腹腔鏡下手術は低侵襲 であり、詳細な視野展開と繊細な手術手技が可能 となる。妊孕性温存術式として腫瘍核出術が明ら かに有用であり、茎捻転の有無にかかわらず第一 に選択することが望ましい。腫瘍径が大きい症例 でも術後追加治療の可能性について理解と同意を 得たうえで選択できると考えられた。

本論文の要旨は第 57 回日本産婦人科内視鏡学会 において発表した。

全ての著者は開示すべき利益相反はない。

倫理委員会承認番号：臨30-60

\section{【参考文献】}

1) Killackey MA, Neuwirth RS: Evaluation and Management of the Pelvic Mass: A Review of 540 Cases. Obstet Gynecol 1988; 71: 319-322.

2 ) Lakkis WG, Martin MC, Gelfand MM: Benign cystic teratoma of the ovary: a 6-year review. Can J Surg 1985; 28: 444-446.

3 ) Anteby EY, et al.: Germ cell tumors of the ovary arising after dermoid cyst resection: a long-term follow-up study. Obstet Gynecol 1994; 83: 605-608.

4 ) Chapron C, et al.: Treatment of ovarian dermoid cysts. Place and modalities of operative laparoscopy. Surg Endosc 1994; 8: 1092-1095.

5 ) Laberge PY, Levesque S: Short-term morbidity and long-term recurrence rate of ovarian dermoid cysts treated by laparoscopy versus laparotomy. J Obstet Gynaecol Can 2006; 28: 789-793.

6 ) Rogers EM, Allen L, Kives S: The Recurrence Rate of Ovarian Dermoid Cysts in Pediatric and Adolescent Girls. J Pediatr Adolesc Gynecol 2014; 27: 222-226.

7 ) Yousef Y, Pucci V, Emil S: The Relationship between Intraoperative Rupture and Recurrence of
Pediatric Ovarian Neoplasms: Preliminary Observations. J Pediatr Adolesc Gynecol 2016; 29: 111-116.

8 ）神保教広、他: 当院における小児卵巣腫瘍58例の検討、 日小外会誌、2011；47：943-947.

9) Oelsner G, et al: Minimal surgery for the twisted ischaemic adnexa can preserve ovarian function. Hum Reprod 2003; 18: 2599-2602.

10) SOGC Clinical Practice Guideline: No.341-Diagnosis and Management Adnexal Torsion in Children, Adolescents, and Adults. J Obstet Gynaecol Can 2017; 39: 82-90.

11）日本婦人科腫瘍学会編：卵巣がん治療ガイドライン 2015年版、2015；56-58、金原出版.

12）上田和、他：腹腔鏡下手術施行後に診断された境界 覀性卵巣腫瘍8例からの検討、日産婦内視鏡学会、 $2014 ; 29: 402-407$.

13) Kikkawa F, et al.: Diagnosis of squamous cell carcinoma arising from mature cystic teratoma of the ovary. Cancer 1998; 82: 2249-2255.

14）牧原夏子、他：卵巣奇形腫における悪性転化の術前 予測についての検討、日産婦内視鏡学会、2014; 30 : 112-116.

投稿日：2019年 1 月 29日 採択日：2019年 6 月 19 日 